\title{
THE SEA, THE MARCH AND SOVEREIGNTY
}

In The Safeguard of the Sea, Rodger claimed that the northern seas in the Middle Ages were "a lawless domain beyond the borders of civilized society". ${ }^{1}$ However, in this chapter I shall argue that this is too simplistic a way of seeing the politico-legal status of the sea in the Middle Ages. In the fourteenth century, there were numerous claims of sovereignty and control over this area, yet even beforehand, it seems as if conflicts were regulated by a custom of the sea expressed in a procedure of conflict settlement akin to, if not identical with, the one used for conflict settlement in the march-areas of England and France.

As we saw in the previous chapter, private justice codified into the letters of marque and arrest was one way of solving conflict and piracy at sea by private persons as well as by the authorities. However, the English and French kings in the first four decades of the fourteenth century tried to reverse this situation by claiming sovereignty over the coastal areas and the immediate waters bordering their kingdoms. This chapter shall deal with the political and judicial status of the sea in relation to conflicts and their resolution. It will provide a framework for marque, reprisals and piratical maritime wars.

I will begin, however, with a tentative definition of the "march" in the Middle Ages. Grossly stated, the expression "march" denoted a border or a frontier. ${ }^{2}$ The march was an old Germanic concept dating to a time of unclear frontiers between lordships and kingdoms. ${ }^{3}$ In France, for instance there were the Burgundy march on the borders with the Empire and the Gascon march in the southwest. In England, there were the Welsh and the Scottish marches. In their specific customs, these marches were distinct from each other, yet they were characterised by certain common

${ }^{1}$ Rodger, Safeguard, p. 79.

2 Godefroy, Dictionnaire, p. 167.

${ }^{3}$ John France calls the general political situation of dominance of land "mouvances, circles of influence based on landownership which rarely coincided with the geographical area of settlement of any nation or any particular geographical unity. Moreover, these circles of influence overlapped heavily". France, John, Western Warfare in the Age of the Crusades 1000-1300 (London \& New York, 1999), pp. 4-5. The marches were an even more accentuated version of this. 
features which lie at the core of the concept of the march. It was thus not a political void, but rather a politically and judicially contested area of overlapping and often conflicting lordships and privileges. Furthermore, it was territorially both distinct and at the same time a fluid area moving with the waxing and waning of seigneuries. In a sense, the march seems to encompass both the modern meanings of the English words "border" and "frontier" (in the American sense), since it was the border between two kingdoms or lordships and at the same time a legal and political frontier with fluid and customary rules subject to third-party arbitration rather than a single prince's jurisdiction. ${ }^{4}$

In his treatment of homage in the French marches from the tenth to the twelfth centuries, Jean-François Lemarignier identified the problem of what a march constituted:

What is thus the nature of the frontier? Is is precise or is it fluid? Is it a line or is it a region more or less difficult to determine? In this regard, the word marca, marcha or marchia, which broadly means 'limit', covers both notions of the term. It sometimes signifies a precise limit, but more often a liminal region and it is in this latter meaning that one speaks of marches governed by a marquis, which are frontier regions organised for security. By extension, marca also signifies a liminal territory. ${ }^{5}$

Thus, we are dealing with a fluid but at the same time a clearly identifiable region distinguished by a high level of insecurity because of its contested geographical position. Consequently, the march is characterised by a high level of martial organisation and a will to use force over law in disputes.

The march concept was vital as long as the medieval kings remained not much stronger than their most powerful vassals. In the High Middle Ages, especially the thirteenth century, when the kings were increasingly asserting their power, supremacy and indeed sovereignty over their

4 Cambridge Dictionaries online. Border: "the line that divides one country from another", http://dictionary.cambridge.org/dictionary/british/border_1 Frontier: "a border between land used to grow crops where people live and wild land," http://dictionary.cambridge.org/dictionary/british/frontier Accessed on 25 February 2011. For a discussion of the terms "border" and "march" in the twelfth and early thirteenth century, see Benham, Jenny, Peacemaking in the Middle Ages: Principles and Practice (Manchester, 2011), pp. 31-32.

5 "Quelle est aussi sa nature [la frontière]? Est-elle précise ou est-elle floue? Est-ce une ligne, ou est-ce une région plus ou moins difficile à déterminer? A cet égard le mot marca, marcha ou marchia, qui a, en gros, le sens de limite, recouvre les deux notions. Il signifie parfois limite précise, plus souvent région limite et c'est dans ce dernier sens que l'on parle des marches gouvernées par les marquis qui sont des régions-frontières organisées pour la sécurité. Par extension, marca signifie aussi territoire limité." Lemarignier, Jean-François, Recherches sur l'hommage en marche et les frontières féodales (Lille, 1945), p. 5. 
vassals and the collective territory that they identified as their kingdom, the conflict between royal power and the denizens and lords of the marches was accentuated. In the words of Lemarignier, "the new political frontier would often coincide with those that had developed from custom which were developing in the tenth to the twelfth century within the framework of the seigneurie. By modelling itself on the customary frontiers, it increases the opposition between the lands which they separate". 6

From a judicial point of view, what Lemarignier stressed here was the clash between royal law and seigneurial law or customs. This was really what lay at heart in the concept of the march from a politico-legal point view, that is, conflicting and overlapping jurisdictions.

\section{TERRESTRIAL MARCHES}

This portrayal of the march as a region characterised by hostilities occurs in numerous sources. For instance, in 1313, the town of Is-sur-Tille in Burgundy effectively submitted to royal control and taxes, on the condition that Philippe le Bel supplied royal protection "By sending the king's men to pursue the malefactors and the banished who, until now because of the proximity of the Empire, were pillaging with impunity the land and march of Burgundy near the Saône in the bailiwick of Sens". ${ }^{7}$ While the situation on the eastern border of the French kingdom is interesting, the situation in England and Gascony has a greater relevance for the mariners' conflicts. Therefore, I devote the rest of this section to a survey of the Welsh march, the Anglo-Scottish march and the Gascon march to achieve a condensation of the concept of the march.

As a region, the Welsh march was a result of the Norman Conquest in 1066 and the forced end to the expansion which the Norman invaders encountered in the Welsh highlands. For protection against Welsh hostilities and to lead offensives against Wales, the lords who came to rule the Welsh march were endowed with special privileges. Amongst these was

6 "la frontière politique nouvelle va souvent coïncider avec celle du ressort de coutume qui s'organise, du Xe au XII ${ }^{\mathrm{e}}$ siècle, dans le cadre de la seigneurie. En se modelant sur les frontières coutumières aggraveront l'opposition entre les pays qu'elles séparent." Lemarignier, Hommage en marche, p. 8.

7 "pour mettre les gens du roi à même de poursuivre les malfaiteurs et bannis qui, jusqu'alors et grâce à la proximité de l'Empire, désolaient impunément la terre et marche de Bourgogne, vers la Saône, au baillage de Sens." Registres du Trésors des chartes, ed. Robert Fawtier, 3 vols. (Paris, 1958-1984), I, no. 1860, p. 374. 
the right, as the only lords in England, to maintain private armies and conduct wars at their own initiative, originally to protect against Welsh aggressions and to lead punitive operations against the Welsh. However, this quickly developed into a right to protect their territories, interests and privileges with armed might against all aggressors. These marcher lords were de facto semi-independent lordships in a region which was defined as separate from Wales proper, as well as separate from the kingdom of England. It was simply called the "Welsh March", which effectively constituted a buffer zone between England and Wales. The Welsh marcher lords were de facto princes of their own little "kingdoms", with, however, a certain degree of dependence on and adherence to the kingdom of England. ${ }^{8}$ According to Rees Davies, the nature of the law of the Welsh march "was a droit coûtumier in the fullest sense, unwritten body of custom whose keepers were the will of the lord, the precedents of the court, and the collective memory of the folk". ${ }^{9}$

Since these lords were semi-independent, disputes and their settlement were under the lords' jurisdiction, yet at the same time they were subject to "international" negotiations like those between the European kingdoms. This problematic relationship, as well as the judicial situation, has been characterised by Davies thus:

The phrase 'the law of the march' was occasionally applied by contemporaries to refer to the regulations, both official and unofficial, whereby marcher lords tried to settle the problems which were bound to arise between one lordship and another in the absence of a central authority. These marcher border regulations-including love-days [meetings for the settlement of disputes], mutual extradition arrangements, letters of march, the practice of disclaimer... were, the international rather than the internal law of march. ${ }^{10}$

This meant that the march of Wales resembled, in at least one regard, the Continental lordships more than their neighbouring English ones. Thus, we can confidently say that the increased hostility, the military organisation and the judicial status of this march conformed to the image given by Lemarignier for the French marches.

8 Davies, R.R., "The medieval state: The tyranny of a concept?," Journal of Historical Sociology, 16 (2003), 294, Lieberman, Max, The March of Wales 1067-1300 (Cardiff, 2008), pp. $3^{-4}$.

9 Davies, R.R., "The law of the march," The Welsh History Review, 5 (1970), 6-7.

10 Davies, "Law of the march," p. 2. 
The Anglo-Scottish march was different to the Welsh one in a number of respects. First of all, Scotland had a king and thus a unifying and legitimate ruler around whom the nobles could rally, something which the Welsh lacked. It was a kingdom like England, and it had to be dealt with in that way. Furthermore, unlike the Welsh march, the Anglo-Scottish march was defined by a written law or custom, agreed by the English and the Scots in 1249. ${ }^{11}$ Before this date, Anglo-Scottish relations and disputes were characterised by a legal vacuum, and settlements were based on ad hoc decisions. The core of the problem was that the kings could not decide on a legal system in an area where both parties claimed jurisdiction. ${ }^{12}$

The 1249 law was established by an Anglo-Scottish commission, and they agreed that marcher cases should be settled by mixed juries with an equal number of jurors from each side. These mixed commissions would convene at traditional border sites like the Priory of Carham to hear and try cases. The essence of the 1249 Marcher Law was the payment of compensation to borderers in matters of homicide, which was provided for through fines, and for theft, full restitution. However, the assessment of damages was a serious difficulty of March Law, and the final method of proof in contested disputes was wager of battle. This trial by combat was maintained throughout the Middle Ages, despite the fact that as a juridical solution it was becoming increasingly frowned upon by kings in the later Middle Ages. ${ }^{13}$ In wartime, however, this means of settlement was suspended. This method of proof meant that the role of the mixed jury in the marcher tribunals was ambiguous and without a formal executive power of decision. ${ }^{14}$

The purpose of the march days and the march law was therefore primarily concerned with redress, to recompense for damages in order to avoid an escalation of the conflict, since the raiding and counter-raiding over the border could eventually develop into open war. ${ }^{15}$ On the general nature of the Anglo-Scottish marcher laws, Henry Summerson writes:

${ }^{11}$ Leges marchiarum, ed. William Nicholson (London, 1705), pp. 1-9.

12 Neville, Cynthia J., Violence, Custom and Law (Edinburgh, 1998), p. 4.

13 Nevertheless, as Vale has pointed out, trial by battle remained vibrant in the aristocratic culture throughout the Middle Ages and eventually gave rise to the aristocratic duelling culture. Vale, Malcom, "Aristocratic violence: Trial by battle in the later Middle Ages," in R.W. Kaeuper, ed., Violence in Medieval Society (Woodbridge, 2000), pp. 159-181.

14 Summerson, Henry, "The early development of the laws of the Anglo-Scottish marches, 1249-1448," in W.M. Gordon and T.D. Fergus, eds, Legal History in the Making: Proceedings of the Ninth British Legal History Conference (London, 1991), p. 32, Neville, Violence, p. 6.

15 Summerson, "Early development," p. 36. 
the Law of Marches were essentially a set of regulations for the prosecution of offences committed by the inhabitants of one country inside the territory of the other, and for the recovery of property stolen or lent across their common border. In theory all acts of theft or violence committed by Scots against Englishmen in the latter's country, and vice-versa, were to be judged on the march in accordance with these laws. In practice, a Scot assaulted in London was unlikely to sue for redress on the Solway or at Reddenburnthough robberies at sea continued to be so justifiable - and the jurisdiction of the laws was effectively limited to the border lands of England and Scotland. ${ }^{16}$

The settlement of marcher disputes mainly had as its focus restitution and compensation rather than punishment, however. Thus, the purpose of the march procedure was not to settle by judge and trial but rather to negotiate a settlement, possibly by compromise. ${ }^{17}$ As we shall see below, this was exactly the procedure for which the Gascons pleaded in 1293 and throughout the first decades of the fourteenth century.

A problem for the kings of England was that, contrary to the Welsh situation, they had to treat with a king, that is, an equal. However, with the imposition of John Balliol as king of Scotland in the 129os, the situation changed, since in order to obtain English support for his claim to the throne, he had to swear an oath of fealty to Edward I for the kingdom of Scotland. ${ }^{18}$ This altered the status of the march law, which in essence had been based on a relation of equality between the king of England and the king of Scotland. From 1296 with the English military intervention in Scotland, march law was suspended, and English justice and law was imposed in the Scottish border-regions to make the conquest real and durable. ${ }^{19}$ This created an Anglo-Scottish situation akin to the Franco-Flemish one with all its problems of rebellion and wars for independence. Thus, during the Scottish wars of the first three decades of the fourteenth century, the march law was reinstituted, but now the English kings imposed royal wardens to guard the peace and assure the settlement of disputes.

This instituting of a warden is interesting, as the English had experience of this from the Cinque Ports, where the warden of the Ports acted as a controller of this strategically important area. Murray compares the situation of the wardens of the English southern coasts with that on the Scottish march. She notes that both areas were administered for security

\footnotetext{
16 Summerson, "Early development," p. 29.

17 Summerson, "Early Development," pp. 32-33 and 39-40.

18 Brown, Michael, The Wars of Scotland, 1214-1371 (Edinburgh, 2004), p. 169.

19 Neville, Violence, p. 15.
} 
and jurisdictional purposes by wardens, whose functions were essentially those of a sheriff. ${ }^{20}$

While the two situations were different, especially since the warden of the Cinque Ports enjoyed a good relationship with the Portsmen, an aspect which was absent in the relationship between the northern wardens and the locals, there is a coincidence in the situation of the political geography of where these wardens were instituted. Both were on the extreme borders or frontiers of the English kingdom, signifying wardens as royal officers guarding border areas with special privileges conceded to them in return for ready and armed assistance in case of invasion or threat to the kingdom. Thus, in a sense, one could consider the warden of the Cinque Ports as a royal marcher-lord, and, as in the Anglo-Scottish march, the Portsmen also enjoyed the right to their own separate court of justice on the Isle of Sheppey. In this regard, the Portsmen were also marcher-men, only this time at sea in the march between England and the Continent. The officer of the warden of the Scottish march was instituted in 1296, but not until the first decades of the fourteenth century were the wardenship and its duties defined more precisely. ${ }^{21}$

In relation to the piracies and maritime wars, the most important march was the Gascon one. Gascony had never really been controlled by the Capetians, and the control of Gascony by the English kings since 1154 had further exacerbated this situation. Since Gascony, apart from the wine production, was a relatively poor and uncontrolled area which no lord had ever been capable of subduing, a culture of guerrae and the quasi-independent right to solve disputes by arms thrived. The dual status of Gascony as a fief under the king of England in his role as duke of Gascony, and at the same time the nominal participation of Gascony in the kingdom of France, led to several and continuous border clashes in the region, with Gascon nobles seeking the aid of either king against their local enemies. Furthermore, a pauperisation of the local aristocracy in the thirteenth century, combined with a fierce martial culture, had led to a significant militarisation of the area. This created the problem that once the spiral of private war was set in motion, it was difficult to halt or control. ${ }^{22}$

20 Murray, Constitutional History, pp. 80-81.

21 See Reid, R.R., "The office of Warden of the Marches: Its origin and early history," The English Historical Review, 32, (1917), pp. 481-485.

22 Vale, Origins, p. 126. 
In 1293, before the outbreak of the Gascon War, the noblemen, prelates and town communities of Gascony sent a description of the custumes des marches au roialme de France to Edward I, clearly to defend themselves against Phillippe le Bel's allegations and citation of them. It contained four articles on the march-procedure. It began with a reference to the procedure in the marcher areas between France and the Empire, the count of Bar, the duke of Lorraine and the count of Burgundy, all marcher-lords, thus attempting to establish a link to the common procedure for dispute settlement in the French marches.

The first article concerns the settlement when prise or trespas had occurred between marchers, especially the officers of the French king and the marcher-lords of the Empire (that is, the above-mentioned lords). Such settlement was to take place at a jour en marche, where one or more persons from each party were chosen as esgardeurs (adjudicators) to hear the complaints and to determine whether each action, prise or trespas, was lawful, that is, justified (presumably as reprisal for some wrong committed by the other party), or whether it was faulty, and thus judge that the trespasser make restitution. This was to be done with all the cases presented, and if the esgardeurs could not agree amongst themselves, the process would be postponed to another day. This was to be conducted with the counsel of people knowledgeable in the marcher custom ("conseil de ceux qi scevent des custumes des marches"). ${ }^{23}$

The second article stated that in cases where the prises and trespasses were committed by private persons, that is, not by officers of the marcherlord, the marcher-lord was not obliged to come to the jour en marche, but instead he had to render justice to his subject. The third article was that if a prise has been committed and an assembly has been made at a jour en marche, the victim could not engage in counter-reprisals (countregagier) if the assembly decided on restitution. Fourth and finally, if the marchers broke up without having reached an agreement, the procedure was postponed, and they were obliged to continue with this last unsolved issue before proceeding to treat a new one, unless something had occurred which altered the situation. ${ }^{24}$ This custom seems primarily intended for lords, but since not only the clergy but also the towns were co-authors of the Custumes, it seems more than likely that "lord" should be understood to include the towns as well as marcher nobles with the right to use force

${ }^{23} E M D P, \mathrm{I}, 364$

${ }^{24} E M D P, \mathrm{I}, 364-365$. 
to settle disputes with other marcher lords. This notion is confirmed by the frequent recourse to force by, for instance, Bayonne to settle differences with its Gascon neighbours. The message of these Custumes was that the Gascons wanted the conflicts with the French king to be settled in this way and not by the king's courts and the judgement by French royal law.

In the Custumes, the sea and maritime conflict is not mentioned, and the immediate interpretation is that this was only applicable to (march) conflicts on land. However, the context makes it probable that maritime conflicts could and should also be solved in this way. This notion is both supported by the process of Montreuil-sur-Mer, 1306 (see below), and the provisions in later Gascon declarations of march law.

Around 1331, the Gascons petitioned Edward III to uphold the ancient rights, customs and privileges of the Gascons in return for their loyalty (presumably against a settlement over their heads with the French king). The core of the argument was the right to be governed in conflict by common judges (esgardiatours), in the manner of elected arbiters at a jour en marche for all conflicts between Gascons and subjects of the king of France, the king of Castile, the king of Navarra or all other marcher lords for all trespasses, whether criminal or otherwise. For "the sea of England", crimes were to be "governed by the laws and statutes made and ordained by the kings of England and published in the Island of Oléron which lies in the said seas of England and which guards the passage between all manner of people that pass those waters". ${ }^{25}$ Here the Rôles d'Oléron and the march-law seem identical, yet there is nothing in the extant versions of the Rôles d'Oléron on conflict at sea, and we are thus left guessing. Between 1337 and 1339, the Gascons demanded once again that conflict with the French should be resolved on land according to march-law and at sea according to the Rôles d'Oléron. The mentioning of the Rôles d'Oléron in relation to march laws and conflict resolution seems to indicate that the same principles were in fact at hand, namely private arbitrage with royal mediators. The exact wording of the rule of the Rôles d'Oléron on maritime dispute mentioned in the original charter is unfortunately damaged beyond readability, which means that we can only speculate about it. The only part that is legible is the following: "And according to the said

25 "trespass fait en la mer Dengleterre, destre gouvernez par les leys et estatuz jadis faitz et ordeinez par les rois Dengleterre et puppliez en lisle Doliron esteant en la dite mer Dengleterre et gardes entre tote maner des gentz passaunz par la mer desusdite." Chaplais, "Règlement des conflits," p. 294. 
laws called the loy de Oliroun once given and made by your ancestors, the kings of England, in regard to goods taken and damages caused in the above-mentioned sea of England". ${ }^{26}$ This seems to be some sort of institution for reprisal and restitution in the vein of that proposed in the march, and I find it reasonable to assume that this was at the core of whichever of the Rôles d'Oléron applied in relation to conflict at sea. On the dorse it further says: "The ancient custom of Gascony called the marque, and in England, the arrest", 27 just like in the 1282 peace treaty between Bayonne and Normandy (see chapter 7). However, an alternative interpretation is that the adjudication of cases of maritime conflict was the prerogative of the kings of England, but as I will show below, this did not necessarily rule out the application of a march law procedure.

Two other documents from the early years of Edward III's reign support this interpretation. In an anonymous commentary by one of Edward III's advisors, Anglo-French disputes in Gascony could only be settled by bipartite commissions as stipulated in march law, that is, at a jour en marche by elected esgardiatores. ${ }^{28}$ This method had been agreed in the peace treaty of Paris in 1327 and was thus the official way for conflict resolution in these areas. A further explanation of how the English understood the practical application of this is supplied by the keeper of documents, Ellis Joneston, from the early part of Edward III's reign. He named two ways of solving disputes in the Gascon march; cognicio communis (a bipartite commission) and cognicio consuetudinaria which was based on march law (that is, private retaliation and reprisals). In essence, Joneston argued that the cognicio communis and the cognicio consuetudinaria were two sides of the same coin. The cognicio communis was to be applied for damages caused in peace-time, and the cognicio consuetudinaria was to follow march law and it applied to negotiations after wars, in time of truce and peace. ${ }^{29}$ Joneston maintained that the essence of the cognicio consuetudinaria was that it permitted "the arrest of bodies and goods

26 "Et solonc les dites loys jadiz ordeinees et faites par voz auncestres, rois Dengleterre, appellees la loy de Oliroun, quant as biens pris et damages donnez en la mier Dengleterre susdite..." TNA C 47/28/5/52, partially reprinted in Chaplais, "Règlement des conflits," pp. 296-297.

27 "Le auncien custume de Gascoinge appelle la mark et [en] Engleterre arrest," EMDP, I, 365 .

28 "diem in [con]fin[i] is et judices communes ad modum arbitri ellectos, esgardiatores vulgariter nuncupatos." EMDP, I, p. 365.

29 Chaplais, "Règlement des conflits," p. 283. 
which in common parlance are called 'marque' in Gascony". ${ }^{30}$ However, the result of this custom most often was the punishment of the innocent while the criminals walked free. This consequently opened up the risk of war between England and France, to the detriment of the crusade to liberate Jerusalem planned by Edward III and Philippe VI. Therefore, the cognicio communis was to be preferred and conducted before things escalated to the use of cognicio consuetudinaria, which in effect occurred as the result of failure to find an amicable solution to a dispute. ${ }^{31}$

Despite the differences between these marches, I argue that they had traits in common and that these stem from the special legal and territorial status of the march. This meant that settlement and the execution of sentences rested on the private persons implicated, with no clear and superior authority to which one could present the issues and expect both parties to respect that authority and recognise its legitimacy in relation to the settlement of the dispute.

So, apart from the conflicting jurisdictions and consequently the higher level of martial organisation to defend these jurisdictions, what further distinguished the march in terms of conflict and its resolution was that:

1. The lords—including towns—-had the right to settle their difference by arms without any direct interference from the kings.

2. Settlement of disputes should be handled by a few people chosen from each side, provided both parties agreed to this. They should adjudicate by equity rather than by law. These should form a commission with an equal number of arbiters from each side, and the commissioners should be people not directly involved in the dispute, and have sufficient integrity recognised by both parties. At the same time, however, they had to be confidantes of the party which appointed them for the commission so that they could protect against unfair decisions.

3. The marcher law or customs were actually more like a framework for the settlement of disputes than a body of law proper. The execution of sentences, however, rested with the plaintiff and the defendant. While royal officials could intervene, they were not authorised nor recognised as an executive body, but rather functioned as a counselling third party. Thus, no single official or sovereign could pass judgement. The

30 'corporum et bonorum arrestaciones, que mark' in terra Vasconie vulgariter nominantur," EMDP, I, 366.

31 EMDP, I, 365-366. 
character of the court was more of a regulated meeting where the parties could present and discuss the issues and reach a settlement.

4. These negotiations of settlement should take place somewhere in the march, commonly agreed upon.

5. The settlement should be unanimous in order to obtain a durable solution to the problem at hand and to avoid hatred and grievances festering. And, by entering upon a march procedure, the plaintiff and the defendant were expected to respect the decision of the commission.

6. To a certain extent the march was an area characterised by a permanent state of truce (that is, latent, but not open war).

\section{A Maritime March}

The above-mentioned marcher areas were all on land, where physical and visible markers of borders, such as fortifications, could be erected and become a physical expression of the political status. However, for the sea this marking of water was more difficult, given the inherently intangible and uncontrollable quality of the sea. The closest one could get to control over the seas was control over the ports, naval patrols of the sea-lanes and finally claims to sovereignty over the waters bordering the coasts of the kingdoms. Yet, around 1300, the kings lacked the resources to make good any of these measures.

The view of the sea in the Middle Ages seems to follow the historian Jacques Le Goff's distinction between culture and nature. On this distinction he wrote:

the fundamental dualism between culture and nature expressed itself through the opposition of that which is built, cultivated, and inhabited (town-castle-village) and that which is essentially wild (the sea and the forest, the Western equivalents of the oriental desert). It thus expressed the difference between men who lived in groups and men who lived in solitude. ${ }^{32}$

This image of a wild and intangible territory can be seen in the portrayal of mariners in medieval literature. For instance, Kimberley Campbell has noted the chansons de geste's depiction of the mariners' superstition and

32 Le Goff, Jacques, "Le désert-forêt dans l'Occident medieval," in J. Le Goff, L'imaginaire médiéval (Paris, 1985), p. 74. The translation is partially based on the one in Le Goff, J. The Medieval Imaginary, A. Goldhammer, transl. (Chicago, 1992), p. $5^{8}$. 
only skin-deep Christianity in the face of danger at sea, ${ }^{33}$ and in his book on the people of the sea in the Middle Ages, Mollat quotes Nicole Oresme and Eustache Deschamps for the sea folk's reputation of pride, unruliness and perfidiousness. ${ }^{34}$ Other more neutral depictions, yet still insisting on the influence of a life in a liminal area on the behaviour of the mariners, are found in the romance Eustache le Moine, where the trickster, runaway monk and pirate Eustache le Moine had been taught black magic in Toledo by the Devil himself. He was therefore was able to manipulate bodies of water through magic. ${ }^{35}$ In another account of Eustache's exploits, the Polistoirie de Jean de Cantorbéry, it was told that Eustache taught his former co-pirate and later slayer, Stephen Crabbe, magic, and that Eustache used magic to make his ship invisible. ${ }^{36}$ In the romance Fouke Fitz Waryn, as in many other chansons de geste, the sea, the islands and the countries surrounding the core of Christian Europe were inhabited by monsters and infidels, thus underlining the opposition sketched by Le Goff. ${ }^{37}$ Admittedly, this does not tell us anything about the mariners' perception of themselves, but it does signal the perception of the character of the space where they plied their trade and the assumed influence of this rough environment on their behaviour. This unruliness and inherently ungovernable nature of actions at sea accordingly connects to the march dispute and settlement procedure.

The sources stating that the areas of sea between England and France were a march are scarce, but in those that exist, the meaning is hard to get wrong. In the introduction to the Liber Horn version of the Lex d'Oleron from 1315, it is stated that "Insula de Olirun sita est in mari Austrino inter Cornubiam et Aquitanium. Et est Marchia inter Aquitanium et Peyto", that is, the island of Oléron is in the march between Aquitaine and Poitou. ${ }^{38}$

In a petition from 1331, the Channel Islanders likewise identified the position of their islands as being in the march of all nations ("la grant

33 Campbell, Kimberley. A., "En haute mer: navire et marin dans la chanson de geste," in M. Lacassagne, ed., Ce nous dist li escris ... che est la verite (Aix-en-Provence, 200o), p. 46.

34 Mollat, Michel, La vie quotidienne des gens de mer en Atlantique $I^{X^{e}}-X V{ }^{e}$ siècle (Paris, 1983), pp. 221-222.

35 Burgess, Glyn, Two Medieval Outlaws: Eustace the Monk and Fouke Fitz Waryn (Cambridge, 1997), p. 75 .

36 Cannon, H.L., "Battle of Sandwich,” p. 668.

37 Burgess, Medieval Outlaws, pp. 166-172.

38 Ward, Medieval Shipmaster, p. 183. This statement is also found at the end of the Rawlinson MS and in the MS in the Liber Memorandorum. See Black Book of the Admiralty, I, p. lx, n. 2 . 
mer en la marche de toutes naciones") and that they therefore always had to be vigilant against assaults. ${ }^{39}$ This notion is repeated in the proceedings of a case of piracy in 1361, when the English Channel is once again described as a march ("en la meer, qest marche entre les deux roialmes").40

In a letter to Philippe VI, probably from 1331, Edward asked for the cessation of prises and counter-prises on sea and land so that trade could prosper unhindered. He stated that these measures should only be used by marcher lords to obtain justice for their subjects because of the damages done by other marcher lords' subjects. This should be settled at peaceful jours marchis, as was agreed in 1303. These jours marchis were to be conducted by eight gardiens de la pees (four English knights and four French knights), who should always be ready to settle cases. Specifically, these guardians were to be two knights from Picardy and the seneschals of Dover and Ponthieu to guard the peace between the mariners of Calais and Winchelsea and the east of England, and two knights from Saintonge and Poitou and two from Gascony to guard the peace between the Normans, the Bretons and the English of the western realms. However, Edward complained that the service of these (French) knights apparently had been negligible; they often failed to meet, and when they did meet, they did not have sufficient mandate to settle the cases, and in fact they had often obstructed the settlement to the great damage of the English. Edward thus asked for a serious resumption of this practice by Philippe. ${ }^{41}$ These knights were effectively an Anglo-French equivalent of the AngloScottish wardens of the march, only they were supposed to deal with maritime conflicts, not those on land. Thus, these statements strongly suggest that in terms of conflict, the sea should also be viewed as a march. However, the best example of the concrete use of march procedure in the adjudication of piracy suits is the process of Montreuil in 1306 .

The Process of Montreuil, 1306

A thoroughly researched example of a jour en marche for the regulation of piracy is the process of Montreuil-sur-Mer in 1306. This process was the

39 "pur ce qils sont enclos de la grant mer en la marche de toutes nacions, par quoi il covient qils soient toutz jours prestz ils ne seyvent quel hure pur defender eux et lour biens et sauver les chateaux et la terre." EMDP, I, 369 .

40 EMDP, I, 370.

$41 E M D P, \mathrm{I}, 389-392$. 
result of the still-outstanding resolution of cases of piracy between English and French subjects from 1292 onwards. Despite the truce between 1297 and 1303 and the peace treaty of Paris in 1303, the settlement of these cases was still pending. At the request of Pope Clement V, Edward I and Philippe le Bel agreed in 1305 to set up a commission to settle these claims once and for all. ${ }^{42}$

In May and June 1306, Edward I's and Philippe le Bel's commissioners met in the Castle of Montreuil, at that time a thriving port town on the English Channel, to settle by a bipartite arbitration commission the issues of piracy. ${ }^{43}$

Apart from the still-pending complaints over piracy, matters were further complicated by the fact that since the peace in 1303, the French had been waging war to crush a Flemish rebellion. During this war, French royal vessels under the command of Admiral Renier Grimaldi, and French mariners such as the Calaisien shipmaster Jean Pédrogue and the commander of the French forces in Calais, Oudard de Maubuisson, had been harassing Flemish maritime commerce by cruising along the Flemish coasts, The Narrow Seas and indeed the English east coast looking for and attacking Flemish ships or "neutral" ships trading with Flanders. These French naval operations entailed numerous attacks on English shipping. In the same period, the English had mobilised to crush the Scottish rebellion, which entailed naval actions against the Scots, but these actions apparently also touched French shipping. Furthermore, as a French vassal, Edward had conceded in secret to provide naval support for the French against the Flemish. ${ }^{44}$ The essence of the process was thus to settle the claims and counter-claims of English and French subjects against each other for piracies in times of truce and peace.

The English and the French each appointed two commissioners for the process. The English appointed Philip Martel, king's clerk, professor of civil law and keeper of processes of records of foreign relations, and the

\footnotetext{
42 Cuttino, G.P., English Diplomatic Administration (Oxford, 1940), p. 51, Champollion, I, 404 and 424-29, Foedera 1273-1307, pp. 900, 936 and 940.

43 Numerous documents for this process exist in the National Archives, under the headings TNA C $47 / 27 / 5, \mathrm{C}_{47} / 27 / 6, \mathrm{C}_{47} / 29 / 5, \mathrm{C} 47 / 29 / 6, \mathrm{C}_{47} / 31 / 19$. A list of all the documents with the old Public Record Office headings can be found in The Gascon Calendar of 1322, ed. G.P. Cuttino (London, 1949), nos. 616-665, pp. 57-61. I do not intend to do a thorough and detailed survey of the complaints in these files, since they do not differ from the picture already presented in the chapter 2 . I will restrict myself to an analysis of the procedure of the process and to the insurmountable problem of the relationship of power between the French and the English kings. To this end, I will mainly follow Cuttino's, Chaplais' and Cheyette's analyses of the Montreuil process.

${ }^{44}$ Foedera 1273-1307, p. 961.
} 
knight John Bakewell. The French appointed Etienne Bourret, sub-dean of Poitiers, and the knight Jean de Ver. They were to form a bipartite commission with the purpose of inquiring into damages and losses suffered to satisfy plaintiffs with a recognised claim and to refer questionable cases to the kings for settlement. ${ }^{45}$

As shown in the previous chapter, the normal way for merchants to obtain restitution were petitions to the king or, if all else failed, to demand the issuing of a letter of marque. This procedure was not a result of law, but rather diplomacy. In contrast, according to Cuttino, "The process of Montreuil was a series of legal cases involving maritime losses brought for hearing and settlement before what amounted to an international commission". ${ }^{46}$ However, the commissioners were not to proceed by French or English law, but rather by equity agreed amongst them, and I agree with Pierre Chaplais that this was effectively a procedure between two marcher-lords and not a trial by sovereign law.

In the process, the plaintiffs had to supply the name(s) of their ship(s), those of the shipmaster(s) and of the owners of the cargo, and the time when the ship left port. Furthermore,

Several facts were to be furnished regarding the actual depredation: the place, and whether it was in sight of others by whom the depredation could be proved; whether it was despoiled off the coast in sight of men on land or of ships at anchor off shore. If the merchandise was removed from one boat into another, sailors who were on board at the time had to testify to this fact. Witnesses were likewise to be produced if the cargo had been seized in port. The remaining information concerned the imprisonment of sailors and the conversion of seized goods into cash. In regard to the former, plaintiffs were to advise the commission of the duration of imprisonment, by whom it was effected, and the means of delivery; that is, 'whether any other merchants of England were in port by whom the seizure of goods can be proved, and whether through a public announcement of them rumour is common in England'. ${ }^{7}$

This procedure does not seem to have been used exclusively at the process of Montreuil; it was probably the procedure applied in any trial over piracy.

There were four types of documents used in the process: general petitions, claims against the French, claims against the English and replications.

45 Cuttino, English Diplomatic Administration, pp. 22 and 51.

46 Cuttino, English Diplomatic Administration, p. 52.

47 Cuttino, English Diplomatic Administration, p. 53. 
Of the first category there were only two documents. They were both written by the proctors of the commonalities of subjects of Edward I. These will be dealt with in detail in the last part of the chapter. Thus, I will confine myself here to a few remarks. In the first general petition, the English argued that since the Scots were allied with the French between 1297-1303, the French were to pay for the English losses at the hands of the Scots. This amounted to a demand of several million pounds in restitution, which the French were to pay by principle of collective liability (that is, the French were allied with the Scots, had helped them and consequently had a responsibility for their allies' actions). This claim must have seemed ludicrous to the French - not the least in comparison with the expenses of the Gascon War. ${ }^{48}$ The second general petition was an English declaration of sovereignty over the English Sea which de facto meant from the English Channel to the Pyrenees. The English argued that since time immemorial, the English had enjoyed an exclusive right to jurisdiction over maritime conflicts.

The individual English claims were presented in the form of a libellus, that is, a statement of the claim of the person, which followed the abovedescribed procedure and in addition to information about the ship, cargo and circumstances of the attack also named the despoilers and where these took the goods after the attack. The claim always ended with a demand for restitution of a certain amount. To this, the defendant almost always replied either by a contestatio negatiua (an alibi) or an exceptio dilatoria (a delaying action), or both. In constatio negatiua, the defendant usually argued that he could not have committed the piracy, since he was somewhere else when the piracy had been committed. Therefore, the defendant pleaded quit of charges or at least the right to a further statement in the case. The exceptio dilatoria was a statement with the intent to delay or stall the process. An example of this would be that if the accused were out of the kingdom and could not be reached at the present time, the case had to be postponed until the accused were found and could come to stand trial. This usually resulted in the plaintiff proposing a repplicatio, which might be a contradiction of the defendant's reply or

48 Cuttino, English Diplomatic Administration, p. 54. According to Cheyette, "Sovereign," p. $5^{2}$, this amounted to $£_{4.2}$ million. To give an idea of the ludicrous amounts demanded in this complaint, the average English annual expenditure for the Gascon War, 12941299, was 238 ,000 l.t. $(£ 59,500)$, which amounted to $83.8 \%$ of the total estimated English annual income, while the average French annual expenditure in this war was 346,000 l.t. $(£ 86,500)$, that is, $61.5 \%$ of the total estimated French annual income. Vale, Origins, pp. $281-282$. 
an offer to bring forth further evidence to the accusation. However, most often the result was that the proctor of the plaintiff had to postpone his cause in order to inquire further into the matter. ${ }^{49}$

Only once did the French defendants come with a real reply. This was the case of the plunder of the ship Michel de Arwe. Pédrogue and Maubuisson admitted to have taken the ship but not in the way described by the plaintiffs. They stated that Edward I (correctly) had prohibited the English from aiding the enemies of France (including trading with them) and that they had entered the ship without use of violence where they had found letters proving that the ship had Bruges as its destination. Therefore, they promptly seized the ship on charges of smuggling and imprisoned the crew. All but one of the prisoners managed to escape from prison, however. According to the French, this proved their culpability, and the ship and goods had been forfeited to Philippe le Bel and not to Pédrogue or Maubuisson for their personal profit.

The French claims against the English followed the same line, but we do not have the replies of the defendants. All in all, the French claimed losses due to piracy for £19,537 6s. 1od. whereas the English only claimed $£ 1,882$ 18s. While the English figure is considerably lower than the French, we must remember that the total of English claims is unknown, since some of the records for this process have not survived, ${ }^{50}$ and it seems as if Cuttino omitted some documents in his account, amongst them the Gascon petitions, while others have been damaged beyond legibility.

The repplicatio were the English plaintiffs' replies to the French defendants' statements. Only two of these are known, and they were addressed to Oudard de Maubuisson and to Renier Grimaldi. Oudard claimed that he acted under orders of the French admiral in the seizing of the ships and that he had surrendered the cargo to the French king. The English, however, would not accept this and instead accused him of plunder of English ships for his own profit. Accordingly, it was not legitimate wartime seizures but common robbery. ${ }^{51}$ However, Oudard questioned the veracity of details of the claims and thus the validity of the claim itself, and he demanded extra proof. Renier Grimaldi simply questioned the evidence of the claims and pleaded innocence.

\footnotetext{
49 Cuttino, English Diplomatic Administration, pp. 56-57.

50 Cuttino, English Diplomatic Administration, pp. 55 and 58.

51 Cuttino, English Diplomatic Administration, p. 59.
} 
These negotiations touched upon the central issue in the process: were the French actions at sea legitimate military actions where French mariners in royal service did their duty and carried out royal orders to stop smugglers and enforce an embargo, or were they abusing their commission to indiscriminately attack all foreigners for their own profit? Obviously, the French claimed the former while the English the latter. The principal French officers indicted in this process were Renier Grimaldi, Jean Pédrogue, and Oudard de Maubuisson, but at least sixteen other French shipmasters were also accused. While these men were all in royal service against the enemies of France, the actions against the English were unmistakably (to the English) piracy, that is, robbery at sea for personal profit. Furthermore, the English complaints show that the French were not only cruising the Flemish coast but also as far north on the English coast as Scarborough, ${ }^{52}$ thus in no provable way near Flanders, and at least some of these actions unmistakably resembles piracy.

The process started out well, but on 15 June it came to a halt. The commissioners met and made a deposition regarding their differences to a public notary. The French stated that they were ready to continue the process but that they also needed to go to Normandy, Poitou and Brittany to hear the complaints there to make sure that everyone was heard. They would then present these complaints to the English commissioners. Afterwards, they would go to England and Ireland to hear and receive complaints there. Only then could they proceed to a final settlement. This apparently came as a surprise to the English, who complained that they had already collected all English complaints, and in any case that they had to consult Edward I before they could proceed and accept the new French proposition. The process was left in status quo and the splitting up of the commission, but the commissioners were to reconvene on 15 October of the same year. ${ }^{53}$

This was effectively the end of the process, because from then on Philippe le Bel insisted that the commission should review the whole relationship of the English kings' vassalage to the French kings. For his part, Edward I wanted only to investigate the cases of damage between the subjects of the two kingdoms and wanted to have two separate commissions, one for losses preceding the Gascon War and another for losses incurred from 1297 to 1306. Thus, Edward tried to restrict the case to the issue of

52 Cuttino, English Diplomatic Administration, pp. 16o-168.

53 Cuttino, English Diplomatic Administration, pp. 62-63. 
piracy and restitution, while Philippe tried to use the cases as a lever to redefine and strengthen his authority over the English king. The English envoys then proceeded to complain to Pope Clement V that the French had been unwilling to award damages and had complicated manners unduly; that Philippe le Bel had in effect protected the defendants; and that his commissioners were partial and had helped the French defendants. The conviction of the accused French was in effect impossible. Furthermore, the English claimed that the French demand of hearing all complaints in France could not be seen as anything but a deliberate obstruction of the case, and the French defendants' claims of alibis in many of the complaints were insincere. ${ }^{54}$ By 15 October, Philip Martel had died, but John Bakewell went to Paris to resume the process, but he could not find the French commissioners, and after having publicly announced the failure to convene he returned to England.

Two cases of the many presented at Montreuil display the problems that this breakdown raised for the victims of French piracy. In the first case, the merchants Geoffrey Turbok of Lynn and Walter de Gosewyk of Berwick-upon-Tweed complained to Edward I and his council in a petition dating to the autumn of 1306 or the winter of 1307 that Philippe le Bel had delayed and defaulted in doing justice to them for French piracy during the truce. Therefore, they asked Edward I to help them receive satisfaction for the goods lost and their expenses according to Law Merchant. ${ }^{55}$ Some time later, their petition was presented at Parliament in January 1307, where the merchants stated that the piracy and the circumstances under which it had happened had been admitted by Pédrogue, who, however, claimed that the goods had been seized for the profit of the French king and not his own. Geoffrey furthermore stated that he had been in Paris in October, the same time as Bakewell, and like him he had not been able to meet the French commissioners either. The merchants thus claimed restitution according to Law Merchant. Interestingly, however, the final English decision was that the petitioners could not be helped. ${ }^{56}$ At that point, the English had apparently realised that any sort of settlement of these out-standing claims was unlikely to take place in the foreseeable future.

\footnotetext{
54 Cuttino, English Diplomatic Administration, pp. 65-66.

55 TNA SC 8/256/12792B.

56 TNA SC $8 / 256 / 12792 \mathrm{C}$.
} 
This did not dissuade other petitioners. In 1300, Pey de Seint Pol, a Bayonnais merchant, had loaded a ship with wool at Lynn to be taken to Saint-Omer, when the ship was attacked by Pédrogue. The French killed the crew and took the ship with the goods to Haut in the county of Dreux. The total losses for Seint Pol were $£_{350}$. Apparently, Pédrogue admitted to this and was presumably to make restitution to Seint Pol, but despite Pédrogue's admission of the piracy, the French commissioners at Montreuil denied restitution. The documents for Seint-Pol's case range from the end of the 1290 s to 1315 , and nothing indicates that restitution was ever obtained. ${ }^{57}$ It is not surprising, however, that the French commissioners refused restitution; if this had been granted in Seint Pol's case over a French soldier and war-hero, it would have made the French actions at sea in general look like piracy and not like legitimate wartime operations. This point does not seem insignificant in the final breakdown of the commission. Thus, both of these cases clearly show that the French did not, in effect, commit to the process. ${ }^{58}$

Cuttino observed that the procedure and the rules for arbitration were borrowed from Roman and canon law, and that furthermore the procedure of the process of Montreuil was heavily influenced by the procedure the Parlement de Paris, where the arbitrators seem to have been merely referendaries of the Parlement, not judges. Indeed, some of the same complaints were later heard in Parlement. According to Cuttino, this influence was confirmed by the composition of the commission. He noted that commissions of the Parlement de Paris in civil or a mixture of civil and criminal cases always had one cleric and one lay member. Strictly criminal cases, however, had two lay members and no clerics, since these could not order corporal or capital punishment. ${ }^{59}$

Chaplais, however, points out that the procedure adopted for the Montreuil process was in fact an old and time-honoured way for the French and the English to settle their differences. From the twelfth to the fourteenth century, when Anglo-French conflicts occurred in times of truce, they were amicably resolved according to the law of the marches. This

57 TNA SC 8/289/14432, Champollion, II, 30, SC 8/273/13633, SC 8/287/14312, Cuttino, English Diplomatic Administration, p. 61, n. 4.

58 This case was still pending in 1321. At that time, Pey de Seint Pol had died while pursing the case. CCR 1313-1318, pp. 181-182 and CCR 1318-1323, pp. 390-391.

59 Cuttino, English Diplomatic Administration, p. 51, n. 9. 
institution was known under the name of dictatores or conservatores treugarum. ${ }^{60}$

While this may also have been the procedure for the Parlement, it was a procedure predating the Parisian Parlement. Instead, Chaplais pointed to the similarities between marcher conflict settlement as described above and the procedure at Montreuil. The naming of a few persons with the power to negotiate a settlement based on equity rather than law was indeed the way in which conflicts and complaints were resolved in the marches of England and France. In defence of this interpretation of the process of Montreuil, Chaplais listed the similarity of procedure between the process and the journées de marche, the choice of the town of Montreuil in lying on the Anglo-French march on land as well as on sea, and the title given the commissioners. The prevalence of reprisals in terrestrial marches in particular, as well as in maritime quarrels, led Chaplais to argue that this was essentially the same thing. ${ }^{61}$

However, in regard to the French's insincere commitment to a settlement, Cuttino and Chaplais agreed. Both claimed that it was clear that the French obstructed the process and never really wanted it to work. Furthermore, Chaplais stated that the French commissioners' authority was, from the outset, more theoretical than practical, and they both stressed the fact that the Montreuil process was only an amiable conference on the surface, since the French commissioners were not neutral but acted more like lawyers for the accused French than as impartial judges. ${ }^{62}$ In this regard, the position of Cuttino and Chaplais seems a bit naïve, however, for it was quite unrealistic to assume that the commissioners from either party would actually be neutral. This is also why the English proposals for a marcher process always contained the proposition that if the arbiters could not agree amongst themselves, the case was to be settled by the kings alone. Indeed, Dean and Gauvard have pointed out the common problem in the Middle Ages of corrupt and partial judges. ${ }^{63}$ This was an

\footnotetext{
60 "Du XII ${ }^{\mathrm{e}}$ au XIV $\mathrm{V}^{\mathrm{e}}$ siècle cependant, les conflits franco-anglais, lorsqu'ils se produisaient en temps de trêve, étaient réglés à l'amiable suivant la loi des marches: c'était l'institution connue sous le nom de dictatores ou conservatores treugarum." Chaplais, "Règlement des conflits," p. 278.

61 Chaplais, "Règlement des conflits," pp. 277 and 279.

62 Cuttino, English Diplomatic Administration, p. 69, Chaplais, "Règlement des conflits," pp. 279-280.

63 Dean, Trevor, Crime in Medieval Europe (London, 2001), pp. 34-41, Gauvard, Claude, "Les juges jugent t-ils?," in C. Gauvard, Violence et ordre public au Moyen Âge (Paris, 2005), pp. 116-130.
} 
inherent weakness in the march dispute settlement institution, since, in order to function properly, it had as a prerequisite that both parties and judges were sincerely committed to a settlement. In practice, it was unrealistic to expect impartiality. The French partiality was to be expected as the men accused were soldiers in the French king's service. They could even argue that they were innocent for one reason or another. These men were French war heroes regardless of whether they had committed piracy against innocent neutrals or not.

This leads to the question of why the French were not really committed to the process and indeed sabotaged it? The resolution of maritime conflicts by the application of a march procedure was not unique to Anglo-French relations, nor was it a model destined to fail. Indeed, in the next chapter I will demonstrate how the English successfully applied this model for settlement of the maritime conflict between the Castilians and the Bayonnais. On the whole, it was a good and applicable model, and in principle the French were not opposed to it. Indeed, they followed it in negotiations with the Aragonese in $1312-13 .{ }^{64}$ What really was at stake, and the reason why the French refused to adhere to the model, were the issues of sovereignty and vassalage.

\section{Sovereignty: The Duke of Gascony, the King of England AND THE KING OF FRANCE}

The medieval idea of sovereignty ${ }^{65}$ derived from the authority of the Roman emperors, and through the Carolingians it was transferred to the Holy Roman Emperor. The notion of sovereignty entailed that the emperor had jurisdictional powers and authority over all other kings of Christendom or, at the very least, those who had been part of the Roman and Carolingian empires. The core of the imperial notion of sovereignty was that: "this supreme authority was indivisible and inalienable: the emperor

${ }^{64}$ Strayer, Reign, pp. 26-30.

65 "The term sovereignty generally denotes the position of supremacy of somebody, or something, in respect of somebody, or something else." Maiolo, Francesco, Medieval Sovereignty (Delft, 2007), p. 79. Thomson, Mercenaries, p. 13: "Sovereignty organizes global political space into territorially bound, 'juridically mutually exclusive and morally selfentailed domains'. It is based on 'an ethics of absolute exclusion'." 
was 'lex animata', legality and justice personified-every human creature was subjected to his will". 66

While this claim never seems to have been completely uncontested in the early and High Middle Ages, it was not until the thirteenth century that it really came under attack, starting formally with Pope Innocent III, who in 1202 declared that in temporal matters the French king had no superior. During the thirteenth century and especially in last quarter of the century, the French kings increasingly contested the emperor's sovereignty. The issue was whether the French king was sovereign de jure or just de facto, the latter of which seemed increasingly indisputable. Against the imperial jurists, the French jurists stated with increasing insistence that the king enjoyed the same legal and political status within his kingdom as the emperor did in his territories, thus stating a de jure independence from imperial authority and making the king the equal of the emperor. ${ }^{67}$ The French jurists asserted the French king's status as imperator in regno suo, meaning that all the privileges and rights applicable to the emperor by virtue of his position were also enjoyed by the French king. ${ }^{68}$ One justification for this was the definite territorial limits of the Empire and the French kingdom: "The basic justification for these territorial limitations of empire and kingdom was found to be the French king's peaceful enjoyment of his possessions [my italics]; the prescriptive acquisition of the king's rights was claimed to be the title for his independence". ${ }^{69}$ This formulation of the French king's claim to sovereignty is important for the English declaration of sovereignty over the seas, as we shall see below. To conclude on the issue of sovereignty and the emperor, by the second decade of the fourteenth century, the royal claim to universal sovereignty finally seems to have become a reality de facto as well as de jure, not just for the French, but for most other European kingdoms.

The medieval notion of sovereignty did not just refer to raw power (potestas), however, but more to authority (auctoritas). Indeed, the prerequisite for ruling and enjoying sovereignty was auctoritas, deriving either from a political community or from God (but in a sense both). Either way,

66 Ullmann, Walter, “The development of the medieval idea of sovereignty," The English Historical Review, 64 (1949), p. 3.

67 Ullmann, "Idea of sovereignty," pp. 9-10.

68 Ullmann, "Idea of sovereignty," p. 15.

69 Ullmann, "Idea of sovereignty," p. 14. 
the prince was conferred with the authority to use his power by somebody else. ${ }^{70}$ Francesco Maiolo thus observes that:

A widely accepted hypothesis is that in medieval sources, the term iurisdictio appeared as synonymous with dominium, as well as imperium, and that in both cases it denoted potestas. These heterogeneous terms are gathered in the semantic area of legal and political discourse that today is occupied by the idea of sovereignty.... In the Middle Ages, jurisdiction played the role of 'synthesis of powers', and, given the needs of feudal society, was one of the most versatile legal tools to exploit. This notion somehow reflected more general concerns, like the concern about the problem of hierarchies of power and their normative foundation. ${ }^{71}$

Technically, for the relationship between the French kings and their vassals (including the duke of Gascony, that is, the king of England), the situation is best described by the argument promoted by Pierre de Mornay, bishop, jurist and advisor to Philippe le Hardi and Philippe le Bel. In 1278 he argued concerning the king's right to the ultimate court of justice that:

Because the king thinks himself a prince, he could grant a rescript to his subjects on whatever matter he wished, provided that the rights of any third party were not completely destroyed. Since the king did not subvert the rights of the barons or other subjects, he could take away their right of appeal. ${ }^{72}$

This clever argument left the nobility's privileges and prerogatives formally intact, while at the same time giving the king the right to override these in his capacity as the supreme judge of any dispute in his kingdom.

I shall now take a closer look at the English declaration of sovereignty. The English claim to sovereignty over the sea of England (that is, the Channel and the French Atlantic coast) was presented by the proctors of the king of England, the nobles and the prelates, and the communities of England and all English royal subjects to the commission at Montreuil. ${ }^{73}$ The claim was that the English kings had "since time immemorial been in the peaceful possession of the sovereign lordship of the Sea of England and the islands in that sea". ${ }^{74}$ This claim to peaceful possession of the sea

70 Maiolo, Medieval Sovereignty, pp. 70-71.

71 Maiolo, Medieval Sovereignty, p. 143.

72 Pennington, Kenneth, The Prince and the Law, 120o-16oo (Berkeley, 1933), p. 100.

73 EMDP, I, 367-369.

74 "du temps qil ny ad memoire du contraire, averoient este en paisible possession de la sovereigne seignurie de la meer Dengleterre et des isles esteans en ycele." EMDP, I, 367 . 
was identical to the French king's claim to sovereignty over his kingdom mentioned above, and furthermore was a recognised fact (according to the English) by Genoa, Catalonia, Spain, Germany, Zeeland, Frisia, Denmark, Norway and the Empire in general. In other words, it was recognised by all mariners sailing the northern seas-except, of course, the French. Thus, the English had the sufficient auctoritas. However, the claim of sovereignty, while expressed as dating to time immemorial, actually had a very clear starting date, namely the reign of King Richard the Lionheart. This reference is important, because during his reign (and his father's) the king of England actually controlled the whole of the territory along the French coast from Gascony to Flanders. Consequently, all policing and settlement of disputes in this area naturally fell under English royal jurisdiction through their officers. The fact that we can pinpoint Richard I as the king to whom the English referred is, however, because of the Gascons' claim in 1331(?) that the Rôles d'Oléron were given by Richard I. ${ }^{75}$ Thus, the English could actually prove that the English kings had traditionally been the law-givers and in possession of jurisdiction over matters in these waters. The fact that this claim was thus applicable not only to the English Channel, but to the whole of the French west coast as well, is shown by this reference; furthermore, it seems supported by an agreement from 1320 between Edward II's council and the envoys of the count of Flanders, where the waters off Crozon, that is, Western Brittany, are called la mer Dengleterre, and the English king's maritime sovereignty here was confirmed by the Flemings. ${ }^{76}$ While in the introductory comments to this document Chaplais stated that this was a reference to the English Channel based on the discussion above, I will maintain that the claim, at least from a theoretical point of view, encompassed the whole west coast and not just the Channel. ${ }^{77}$ The English further claimed that even the French

75 While our earliest direct reference to Richard I as giver of the Oléron laws is from about 1331 (Chaplais "Reglement des conflits," p. 294), most of the historians who have examined the subject of their origin agree this really seems to have been the case. See Ward, Medieval Shipmaster, p. 20, Chaplais, "Reglement des conflits," p. 276, Krieger, Ursprung, p. 41, Pardessus, Collection des lois, I, 289.

76 Foedera 1307-1327, pp. 146 and 149, EMDP, I, 414. This document referred to English sovereignty over the seas, including the Breton waters ("il est seignur de la mer et la dite roberie fut fait sur la mer denz son poer"). It is unlikely that this was the general opinion in the northwest in the Middle Ages, however. The French most certainly contested it, and the only immediate reason for the Flemings to accept it was that it would provide them with restitution.

77 EMDP, I, 414. Interestingly, Chaplais states in "Reglement des conflits," p. 271, that this sovereignty was claimed from the Pyrenees to Flanders. 
had recognised this sovereignty in the Treaty of Paris, 1259. The general petition of 1306 effectively stated that, through their admirals, the English kings had the lawful right to high and low justice at sea, to ensure the peace at sea and to police it against prospective pirates. ${ }^{78}$

Apart from this claim to sovereignty, the petition contained three other points. The first was that the kings of England and France had entered an alliance (in 1303) of reciprocal support against all who would infringe upon their "franchises, liberties, privileges, rights, jurisdictions and customs". ${ }^{79}$ While this seems to have been derived from the English kings homage for Gascony to the kings of France, here it was presented as if the kings were equals, that is, two sovereigns and not a lord and a vassal.

The second point was a complaint over Renier Grimaldi, the admiral of France, for his actions at sea against English merchants during the war with Flanders. He had attacked English ships, taken their goods for the French king and had the mariners imprisoned. Not only had the admiral acknowledged this in writing, but he also claimed that it was part of his commission of admiralty. He thus asked to be acquitted. Since this was a usurpation of the English king's juridical prerogatives and an infringement on the English king's sovereignty, Grimaldi had caused great damage to the English. The procurators therefore demanded hasty liberation of the prisoners and their goods, and the prisoners were then to be presented to the English admiral, who had rightful jurisdiction. Furthermore, the English demanded that Grimaldi should be condemned to make satisfaction for all the damages he had caused, or, in case of default, the king of France was to cause it, since Grimaldi was his officer. After satisfaction had been made, Grimaldi should be punished for the damages, his contempt for the Anglo-French treaty and indeed for the usurpation. This punishment should be so severe that it set an example for the future.

Thirdly, in time of war against the Scots, no English mariner should answer to any authority other than the English admirals, and they could not be taken to court for actions against Normans and Bretons for any actions done at sea in time of the truce and the peace. In other words,

78 "especialment par enpeschement mettre et justice faire et seurte prendre de la pees de tote manere des gentz usanz armes en la dite meer ou menantz neefs autrement apparaillees ou garniz qe nappartenoit au neef marchande et en tous autres points en queux homme peut avoir reasonable cause de suspicion vers eux de roberie ou de meffaitz." EMDP, I, 367-368.

79 "franchises, les libertes, les privileges, les droiz, les droitures et les custumes," EMDP, I, 386 . 
only English officers could judge English subjects-no matter what the French said.

In opposition to Cuttino's and Chaplais' assessment of the French as the ones solely responsible for the breakdown of the Montreuil process, Frederic Cheyette argues that the English were far from blameless. Focusing on the outrageous demand for millions of pounds in reparations for the losses caused by the Scots, the assertion of English sovereignty at sea and the demand for punishment of Grimaldi, Cheyette claims that the English approach to the process and the claim of sovereignty over the seas was rather to assert that "the English claims against the French should be heard by an English court without the interference of the bipartite commission. The petition's purpose was to deny the arbiters any competence". ${ }^{80}$ Accordingly, Cheyette argued that the English claim of sovereignty was really just an action to disqualify the commissioners, and that it was in fact an English counterattack to the French claim of sovereignty. The problem was that while the kings of England and France were equals in times of war and truce due to feudal law, in peace time, the French king was the legitimate superior of his vassal, the duke of Gascony, and thus also the superior of the king of England. ${ }^{81}$

So, how should we understand these English claims of several million pounds in restitution, of sovereignty over the seas and of the punishment of the French admiral? Were they a sincere demand or rather a bargaining tool in order to bring the kings of England and France to a level of equality? The first thing that we must bear in mind is that the demand was not actually put forward by Edward I himself but rather by his subjects. While this seems to have been a clever device to exculpate Edward of any deliberate obstruction of the process, and the demand can hardly have displeased the king, in all likelihood his jurists were behind the formulation. However, by having his subjects named as the authors of the document, Edward could permit himself to relinquish some of its demands and claim that he was acting on the will of the people. In that regard, it must be seen as a bargaining tool rather than a sincere demand. To the French commissioners and Philippe le Bel, however, the demands must have seemed so outrageous that they could hardly have been taken as anything but an extreme English overstatement of their demands and consequently an attempt to obstruct the process. While this may have

80 Cheyette, “Sovereign," p. $5^{2 .}$

81 Cheyette, "Sovereign," pp. 52-53. 
fitted rather well with Philippe's plans, it actually left little room for the French commissioners to negotiate, since by these demands the English were trying indirectly to circumvent the relation of power between the two kings, something that Philippe le Bel would not allow. The conclusion must be that, in their attempt to gain a position of equality with the French, the English had overplayed their hand. Their demands were simply too exigent to work properly as a bargaining tool. Thus, while Edward seemed to be sincere in his wish for a settlement of the piracy cases by the process, these claims made the English lay just as much blame on the English as the French for the failure of the process. The English claims of sovereignty were not an expression of actual English control of seas or war on pirates, but a political response to French sovereignty. While piracy was the cause of the process of Montreuil, it was not the real objective of the English commissioners. ${ }^{82}$

In any case, the English declaration of sovereignty over the sea was obviously unacceptable to the French, and in a case of piracy against Rochelais merchants in 1311, Philippe le Bel declared that it had happened "in mari infra districtus nostros", that is, in French controlled waters. ${ }^{83}$ Consequently, Philippe demanded the extradition of the pirates so that they could be prosecuted at a French court of justice. This case shows that Philippe by no means accepted sole English maritime jurisdiction, nor for that matter that the sea was under English sovereignty. For his part, Edward II denied the extradition but promised to put the mariners before an English court. Only if the English laws were insufficient would he allow extradition, but needless to say, Edward assumed them more than adequate. ${ }^{84}$

The reason why the process of Montreuil seemed doomed from the outset can be summed up thus: the English, supported by Gascon customs for marcher-law in the settlement of conflict in border areas and a version of the Rôles d'Oléron for conflict at sea, claimed settlement by marcher procedure, since this entailed that the kings of England and the kings of France would treat with each others as equals. ${ }^{85}$ The irreconcilability of these claims in terms of maritime conflicts was in no small part due to the French king's tendency to assimilate crimes committed at sea by the English king's Gascon subjects against French mariners to a purely feudal

82 Rodger, Safeguard, pp. 78-79.

83 Foedera 1307-1327, p. 146.

84 Foedera 1307-1327, pp. 146 and 149.

85 Chaplais, "Reglement des conflits," p. 273. 
conflict where the French king was the only and supreme judge. ${ }^{86}$ For the French, any claim of sovereignty pertaining to French affairs was completely unacceptable. While the French kings were not opposed to the practice of handling conflict along the lines of marcher settlement, they were opposed to journée en marche with the English, since it would make the two kings equals, a prerequisite for a functioning march procedure. As long as the English king was the French king's vassal, the French would never agree to treat with them on the same footing. ${ }^{87}$

This chapter has thus provided part of the reason why pirates were not prosecuted. Apart from the troubles of identifying whether the persons indicted had indeed committed the piracy or not, the Anglo-French piracy process of Montreuil was in the end more concerned with foreign policy, and the feudal relationship between the kings always took precedence over the individual cases of injustice. For the process of Montreuil, the procedure applied also makes it more than likely that what was used as legal procedure was the one of the marches, only now for the sea. This effectively rendered the sea into a march. This meant that the maritime communities waging war in effect were to be seen as marcher lords with the right to wage war like their Gascon counterparts.

86 Chaplais, "Reglement des conflits," p. 271.

87 Chaplais, "Reglement des conflits," pp. 278, 281 and 284. 